\title{
Organic Dairy Production based on Rapeseed, Rapeseed Cake or Cereals as Supplement to Silage ad libitum
}

\begin{abstract}
Mogensen, L., Ingvartsen, K. L., Kristensen, T., Seested, S., Thamsborg, S. M. (Danish Institute of Agricultural Sciences, Research Centre Foulum, P.O. Box 50, DK-8830 Tjele, Denmark, and Royal Veterinary and Agricultural University, 1870 Frederiksberg C, Denmark). Organic dairy production based on rapeseed, rapeseed cake or cereals as supplement to silage ad libitum. Accepted March 4, 2003. Acta Agric. Scand., Sect. A, Animal Sci. 54: 81-93, 2004. (C) 2004 Taylor \& Francis.
\end{abstract}

This experiment presents the effect of $100 \%$ organic feed rations grown at an equal area per cow on milk production performance and metabolic responses. A total of 174 Danish Holstein cows were included in two experiments on two commercial organic dairy farms during the winter 2000/2001. Three types of supplementary feed were examined: $5 \mathrm{~kg}$ cereals, $3 \mathrm{~kg}$ rapeseed/cereal pellet or $1 \mathrm{~kg}$ rapeseed cake fed with a mixture of clover grass silage, whole crop silage and grass pellets $a d$ libitum. The supplement of rapeseed/cereal pellet compared with cereals tended to decrease both milk fat and protein content, whereas fat and protein yield were unaffected. Milk yield was increased by supplement of rapeseed/cereal pellet compared with cereals in experiment 1 , but unaffected in experiment 2. Consequently, energy corrected milk yield tended to be increased in experiment 1 but decreased in experiment 2 . The supplement of rapeseed cake compared with cereals changed neither milk composition nor yield. The risk of subclinical ketosis based on metabolic parameters and other metabolic disorders was not affected by the different feedings.

\author{
Lisbeth Mogensen ${ }^{1}$, Klaus L. \\ Ingvartsen ${ }^{1}$, \\ Troels Kristensen ${ }^{1}$, \\ Susanne Seested ${ }^{1}$ and Stig M. \\ Thamsborg ${ }^{2}$
}

${ }^{1}$ Danish Institute of Agricultural Sciences, Research Centre Foulum, P.O. Box 50, DK-8830 Tjele, Denmark, and

${ }^{2}$ Royal Veterinary and Agricultural University, 1870 Frederiksberg C, Denmark

Key words: $\beta$-hydroxybutyrate, dairy cow, fatty acids, glucose, metabolic responses, milk production, NEFA, organic farm, roughage.

\section{Introduction}

Organic dairy production in Denmark has, to date, been based on a high proportion of homegrown roughage, barley and a small amount of imported conventionally grown concentrate, often rapeseed cake. According to EU legislation, the use of $100 \%$ organically produced feedstuffs is a demand for all organic cows in Europe from 2005 onwards (Council for The European Union 1999), and in Denmark 100\% organic feeding is already demanded by the majority of the dairy industry. Moreover, one of the basic principles in organic farming, identified as the cyclical principles
(IFOAM 2000), implies working in closed cycles using local resources. Therefore it is logical for farmers to produce the fodder on the farm. Consequently, available land per cow becomes a limiting factor.

The challenge for a $100 \%$ organic feed ration for high yielding dairy cows based on home-grown feed is to match the need for energy and nutrients with crops which can be grown in an organic crop rotation under northern European conditions. The relevant crops in this region are primarily clover grass for silage and grass pellets, barley for whole crop silage and as supplement, and rapeseed used directly as seed or as 


\section{Mogenesen et al.}

rapeseed cake. As the expected crop yield in terms of net energy is highest in clover grass and higher in barley compared to rapeseed, it appears sensible to formulate a feed ration with a high proportion of clover grass silage, and barley as the only concentrate. However, such a ration probably will not match the needs for nutrients and energy of a high yielding dairy cow as the ration will be fairly high in starch, and low in fatty acids and amino acids. Compared with barley, a supplement of rapeseed gives a higher level of fatty acids and energy in the ration. However, growing rapeseed is more risky than growing barley. Therefore, the reason for choosing rapeseed rather than barley might be an expectation of an increased milk yield.

Organic feeding based on a higher than traditional proportion of roughage creates a lower energy density in the ration at the beginning of the lactation (Waldo, 1986; Dhiman et al., 1995). This may increase the degree of negative energy balance immediately after calving (Dhiman et al., 1995) and result in an increased non-esterified fatty acid (NEFA) and a decreased glucose concentration in plasma. It follows that hepatic ketogenesis increases (Kronfeld, 1982), and subsequently the concentration of ketone bodies in plasma and milk increases (Kunz et al., 1985), which is a risk factor for ketosis (Enjalbert et al., 2001).

The aim of this paper was to study the milk production performances of, and selected metabolic responses to, three types of $100 \%$ organic rations grown at a given area per cow and based on barley, rapeseed and clover grass.

\section{Materials and methods}

Two experiments were conducted on two commercial organic dairy farms. In experiment 1 three, and in experiment 2 two, rations were compared. The three types of supplementary feed examined were: cereals (treatment C), a mixture of rapeseed and cereals (treatment $\mathrm{R} / \mathrm{C}$ ) and rapeseed cake (treatment $\mathrm{R}$ ). The roughage was a mixture of clover grass silage, whole crop silage and grass pellets. These rations were formulated so that they all could be grown at the same area per cow, assuming crop yields of $3,700 \mathrm{~kg}$ dry matter (DM) per ha in cereals; $5,800 \mathrm{~kg} \mathrm{DM} / \mathrm{ha}$ in whole crop; 6,200 kg DM/ha in clover grass (Mogensen et al., 1999), and 2,200 $\mathrm{kg} \mathrm{DM} / \mathrm{ha}$ in rapeseed.

The experiments were conducted from November 2000 to April 2001. First, a two-week adjustment period was instigated, followed by an eight-week experimental period (period 1) and, subsequently, another eight-week experimental period (period 2) was carried out which only included cows less than 12 weeks from the latest calving. Period 2 was included to increase the number of cows having an early lactation period for the blood and milk sampling for metabolic analyses. Data from period 2 were not included in the analysis of milk yield responses and feed intake. Both experiments were conducted in loosehousing systems with slatted floors and straw bedded cubicles. The average milk yield per cow per year was $8,000 \mathrm{~kg}(4.17 \%$ fat and $3.28 \%$ protein) on the farm where experiment 1 was conducted, and $7,800 \mathrm{~kg}$ $(4.25 \%$ fat and $3.38 \%$ protein) on the farm where experiment 2 was conducted. All cows were Danish Holstein. The cows were milked twice a day between $05.30-07.30$ and $16.00-18.00$ hours.

\section{Feeding}

The planned experimental feeding is shown in Table 1, and the chemical composition and feeding values of the different feedstuffs are shown in Table 2.

In experiment 1, cows were fed either barley (treatment $\mathrm{C}$ ) or a rapeseed/cereal pellet (treatment $\mathrm{R} / \mathrm{C}$ ), or rapeseed cake (treatment $\mathrm{R}$ ) as supplemen-

Table 1. Planned intake of supplemental feed in kg dry matter (DM) per cow per day and in brackets Scandinavian Feed Unit (SFU)

\begin{tabular}{|c|c|c|c|c|c|}
\hline \multirow[b]{2}{*}{ Treatment } & \multicolumn{3}{|c|}{ Experiment 1} & \multicolumn{2}{|c|}{ Experiment 2} \\
\hline & $\begin{array}{l}\text { C } \\
\text { Cereals }\end{array}$ & $\begin{array}{l}\text { R } \\
\text { Rapeseed cake }\end{array}$ & $\begin{array}{l}\mathrm{R} / \mathrm{C} \\
\text { Rapeseed/ } \\
\text { cereals }\end{array}$ & $\begin{array}{l}\text { C } \\
\text { Cereals }\end{array}$ & $\begin{array}{l}\mathrm{R} / \mathrm{C} \\
\text { Rapeseed/ } \\
\text { cereals }\end{array}$ \\
\hline Cereals & $4.5(5.0)^{1)}$ & - & - & $4.3(4.6)^{2)}$ & - \\
\hline Rapeseed/cereals & - & - & $2.6(4.0)^{3)}$ & - & $2.6(4.0)^{3)}$ \\
\hline Rapeseed cake & - & $0.9(1.1)^{4)}$ & - & - & - \\
\hline
\end{tabular}

\footnotetext{
1) Barley.

2) $35 \%$ barley, $36 \%$ oats, and $29 \%$ triticale (percentage of weight).

3) $50 \%$ rapeseed, $25 \%$ barley, and $25 \%$ wheat (percentage of weight).

4) $14 \%$ fatty acids.
} 
tary feed (Table 1). All cows in experiment 1 had access to ad libitum roughage consisting of $63 \%$ clover grass silage, $19 \%$ barley and pea whole crop silage and $18 \%$ grass pellets ( $\%$ of DM). In experiment 2 , cows were fed either a mixture of barley, oats and triticale (treatment $C$ ) or fed the same type of rapeseed/cereal pellets as in experiment 1 (treatment R/C). All cows in experiment 2 had access to ad libitum roughage consisting of $20 \%$ clover grass silage, $53 \%$ barley and pea whole crop silage, and $27 \%$ grass pellets.

The level of supplementary feed was increased to the planned levels in the treatments (Table 1) during the first four or two weeks of lactation in experiments 1 and 2, respectively. The supplementary feed was fed individually and restrictedly to each cow irrespective of milk yield, and according to the different treatments via an automatic feeding station. The feed allowance was fed over a minimum of six visits per cow per day. The roughage was available at the central fodder area. The roughage was mixed automatically by a mixer wagon before feeding and fed once a day. During the two-week adjustment period, cows within the experiments received the same amount and type of supplementary feed.

The silage used was conserved without use of additives. The clover grass silage had been wilted prior to cutting, while the whole crop silage was harvested directly. The clover grass in experiment 1 was 1 st cut ( $22 \%$ of DM was clover) while 2 nd cut ( $31 \%$ clover) was used in experiment 2. The clover content was examined by visual inspection of the fields after cutting. All roughage was stored in horizontal silos. All silage was by inspection examined as of good quality, and in experiment 1 the number of anaerobe spores was found to be below 200 per g DM. Rapeseed, barley and wheat were ground and pressed to pellet form by a commercial factory (DLG) with a maximum processing temperature of $82^{\circ} \mathrm{C}$. The same batch of pellets was used in the two experiments.

\section{Animals}

Cows in each experiment were blocked according to days in milk, days expected to next calving, and parity (1st, 2nd or older) before randomly allocated to the treatments. All cows less than 30 weeks from calving at the beginning of period 1 were included in period 1 . At the beginning of period 2, only cows less than 12 weeks from calving continued and all cows were excluded when reaching week 12 of lactation. During both periods, cows that calved were included in the experiment and randomly allocated to treatments according to a predetermined blocking. In experiment 1, 76 cows with a daily yield of $26.5 \mathrm{~kg}$ energy corrected milk (ECM) and a live weight of $569 \mathrm{~kg}$ were included at the beginning of period 1 . An additional 12 cows were included at calving during the experimental periods. In experiment 2, 63 cows with a daily ECM yield of 27.9 $\mathrm{kg}$ and a live weight of $611 \mathrm{~kg}$ were included at the beginning of experimental period 1 . An additional 23 cows were included at calving during the experimental periods.

All procedures involving animals were approved by the Danish Animal Experiments Inspectorate and complied with the Danish Ministry of Justice Law No. 382 (June 10, 1987) and Acts 739, (December 6, 1988) and 333 (May 19, 1990) concerning animal experimentation and care of experimental animals.

\section{Recordings and calculations}

Intake of supplementary feed was recorded over $24 \mathrm{~h}$ each day for the individual cow. Intake of roughage was recorded over $24 \mathrm{~h}$ for all lactating cows in the herd once every second week. Cows within experiment were assumed to have the same feed intake capacity, and the roughage was divided among treatments so that the same fill of the total ration was reached in all treatments according to the fill system (Strudsholm et al., 1999). Samples were taken of roughage and analysed for DM, ash, crude protein, sugar, starch, crude fibre (Helrich, 1990), and in vitro digestibility of organic matter (Tilley \& Terry, 1963) every second week. Amino acids absorbed from the small intestine (AAT) and protein balance in the rumen (PBV) were calculated based on the chemical fractions according to Madsen et al. (1995). Digestible protein, digestible cell walls and energy content were calculated according to Strudsholm et al., (1997). Tabulated values were used for rapeseed/cereal pellets, cereals and rapeseed cake (Strudsholm et al., 1997).

Cows were weighed and the body condition score (BCS, 1-5 points, with 0.5 -point intervals (according to Kristensen, 1986) was recorded before the experiment and after the end of periods 1 and 2. Individual milk yields (True-tester) and milk content of fat, protein, urea and somatic cell counts (SCC) were determined over $24 \mathrm{~h}$ (MilkoScan FT 120 infared analyzer, Foss Electric A/S, 3400 Hillerød, Denmark) every second week, beginning in the adjustment period. All veterinary treatments were recorded by the local vet and collected at the Central Danish Cattle Database. ECM was calculated as defined by Sjaunja et al. (1990):

$$
\begin{aligned}
\mathrm{ECM}= & \text { Milk yield } \times(383 \times \text { fat } \%+242 \times \text { protein } \% \\
& +780.8) / 3140 .
\end{aligned}
$$

Blood and milk samples for metabolic analyses were only taken for cows less than 12 weeks from calving. Milk and blood samples were taken every two weeks after the morning milking in experiment 1 , and after the evening milking in experiment 2. Blood samples 
Table 2. Chemical composition ( $/ \mathrm{kg} \mathrm{DM}$ ) and feeding value per $\mathrm{kg}$ DM of the feedstuffs in the two experiments (averages)

\begin{tabular}{|c|c|c|c|c|c|c|c|c|c|c|c|c|}
\hline & \multicolumn{6}{|c|}{ Experiment 1} & \multicolumn{6}{|c|}{ Experiment 2} \\
\hline & Barley ${ }^{1)}$ & $\begin{array}{l}\text { Rape seed/ } \\
\text { cereals }^{1,2)}\end{array}$ & $\begin{array}{l}\text { Rape } \\
\text { seed } \\
\text { cake }^{1)}\end{array}$ & $\begin{array}{l}\text { Clover } \\
\text { grass } \\
\text { silage }\end{array}$ & $\begin{array}{l}\text { Barley dc } \\
{[90] \text { pea }} \\
\text { whole crop }\end{array}$ & $\begin{array}{l}\text { Grass } \\
\text { pellets }\end{array}$ & Cereals $^{1,3)}$ & $\begin{array}{l}\text { Rape seed/ } \\
\text { cereals }{ }^{1,2)}\end{array}$ & $\begin{array}{l}\text { Clover } \\
\text { grass } \\
\text { silage }\end{array}$ & $\begin{array}{l}\text { Barley/pea } \\
\text { whole crop }\end{array}$ & $\begin{array}{l}\text { Pea whole } \\
\text { crop silage }\end{array}$ & $\begin{array}{l}\text { Grass } \\
\text { pellets }\end{array}$ \\
\hline $\begin{array}{l}\text { Crude } \\
\text { protein }\end{array}$ & 119 & 167 & 310 & 162 & 108 & 171 & 118 & 167 & 188 & 126 & 177 & 196 \\
\hline Starch & 607 & 324 & 24 & 10 & 218 & 0 & 578 & 324 & 15 & 159 & 160 & 0 \\
\hline Sugar & 20 & 44 & 100 & 23 & 21 & 131 & 23 & 44 & 33 & 23 & 27 & 129 \\
\hline $\mathrm{AAT}^{4)}$ & 97 & 83 & 148 & 76 & 64 & 89 & 92 & 83 & 64 & 64 & 63 & 94 \\
\hline PBV ${ }^{5)}$ & -52 & 41 & 89 & 22 & -10 & 14 & -37 & 41 & 65 & 9 & 62 & 28 \\
\hline $\begin{array}{l}\text { Digestible } \\
\text { protein }\end{array}$ & 73 & 130 & 258 & 121 & 71 & 111 & 79 & 130 & 145 & 88 & 137 & 133 \\
\hline Fatty acids & 20 & 224 & 139 & 18 & 13 & 20 & 28 & 224 & 17 & 13 & 13 & 20 \\
\hline $\begin{array}{l}\text { Digestible } \\
\text { cell walls }\end{array}$ & 109 & 106 & 246 & 556 & 325 & 343 & 94 & 106 & 448 & 364 & 321 & 360 \\
\hline $\mathrm{DE}$ & 15.15 & 19.35 & 16.89 & 13.70 & 12.37 & 11.72 & 14.82 & 19.35 & 13.41 & 12.28 & 12.59 & 12.58 \\
\hline$M E^{6)}$ & 13.11 & 16.02 & 14.35 & 11.73 & 10.65 & 9.99 & 12.86 & 16.02 & 11.41 & 10.53 & 10.66 & 10.70 \\
\hline SFU ${ }^{7)}$ & 1.11 & 1.52 & 1.27 & 0.97 & 0.71 & 0.68 & 1.07 & 1.52 & 0.84 & 0.73 & 0.78 & 0.79 \\
\hline $\begin{array}{l}\text { Digestibility } \\
\text { in vitro }\end{array}$ & - & - & - & 82 & 68 & 67 & - & - & 75 & 70 & 72 & 73 \\
\hline
\end{tabular}

\footnotetext{
1) Tabular values (Strudsholm et al. 1997).

2) $50 \%$ rapeseed, $25 \%$ barley and $25 \%$ wheat (\% of $\mathrm{kg}$ ).

3) $35 \%$ barley, $36 \%$ oats and $29 \%$ triticale (\% of $\mathrm{kg})$.

4) Amino acids absorbed in the small intestine.

5) Protein balance in rumen.

6) Metabolizable energy, MJ.

7) Net energy expressed as Scandinavian Feed Unit.
} 
were taken from the tail vein $(10 \mathrm{ml})$ and centrifuged for $20 \mathrm{~min}$. Plasma was separated into tubes and frozen for later analysis of $\beta$-hydroxybutyrate, nonesterified fatty acids (NEFA) and glucose. Approximately $7 \mathrm{ml}$ milk from the right rear gland was sampled and frozen for later analysis of $\beta$-hydroxybutyrate. Metabolites in plasma and milk were analysed using an autoanalyser, OpeRA ${ }^{\mathrm{TM}}$ Chemistry Systems (Bayer Corporation). The method for $\beta$-hydroxybutyrate was slightly modified from Harano et al. (1985). The method is based on the increased absorption at $340 \mathrm{~nm}$ caused by the development of $\mathrm{NAD}^{+}$from $\mathrm{NADH}$ at a slightly alkaline $\mathrm{pH}$ in the presence of $\beta$-hydroxybutyrate dehydrogenase. NEFA was analysed by use of acylCoA synthetase and acylCoA oxidase, the ACS-ACOD-method, as prepared by Wako Chemicals (Wako Chemicals USA, Inc Richmond VA, USA.). Glucose was analysed using a combined hexokinase and glucose-6-phosphate dehydrogenase method according to procedures by Technicon RA ${ }^{\circledR}$ Systems as described by Mashek et al. (2001).

\section{Statistical analyses}

Cows with at least three milk recordings were included in the statistical analysis of milk production performances. The average daily milk yield per cow was calculated as a simple average of the registrations during period 1. Concentration of metabolities in plasma and milk: $\beta$-hydroxybutyrate, NEFA, glucose in plasma, and $\beta$-hydroxybutyrate in milk, was transformed by the logarithm, and a simple average per cow of the registrations during the first 12 weeks post partum was calculated.

Effect of treatment on yield and metabolites in milk and blood was analysed both for each experiment separately and for the shared treatments $\mathrm{C}$ and $\mathrm{R} / \mathrm{C}$ in an aggregated analysis using the General Linear Model (SAS Institute 1990) and the following model:

$$
\begin{aligned}
\text { Yield }= & \text { treatment }+ \text { experiment }+ \text { parity }+ \text { treatment } \\
& \times \text { experiment }+ \text { treatment } \times \text { experiment } \\
& \times \text { parity }+ \text { days in milk }+ \text { days in milk } \\
& \times \text { parity }+ \text { yield before experiment }
\end{aligned}
$$

where yield is the depended variable; treatment is the fixed effect of the three supplementary feeds; experiment is the fixed effect of experiment 1 or 2; parity is the fixed effect of 1 st lactation or older $(\geq 2 \mathrm{nd}$ lactation); days in milk is the linear effect of the average interval per cow from calving (covariate), and yield before the experiment is the linear effect of the last milk yield recorded for each cow before the experiment ( $\mathrm{kg} \mathrm{ECM}$ or $\mathrm{kg}$ milk, fat percentage, protein percentage, $\mathrm{kg}$ fat, $\mathrm{kg}$ protein, urea) standar- dised to an average of 0 and the standard deviation of each variable within experiment and lactation number (covariate). Standardisation was made in order to include the cows that calved during the experiment as they were included with 'neutral' value; 0 .

Live weight gains and changes in BCS during the experiment were calculated as the difference between the level at the end of period 1 and at the beginning of the experiment, and analysed by the model above. Live weight or BCS at the first registration at the beginning of the experiment was included as a covariate.

SCC was transformed by the logarithm and a simple average per cow of the registrations was calculated and analysed by the model above. Log (SCC) from the last registration before the experiment was included as a covariate.

Differences in health recordings were tested using an $\chi^{2}$ test (SAS Institute, 1990).

\section{Results \\ Daily feed intake per cow}

Table 3 shows the daily feed intake per cow. The cows always ate the offered amount of supplements, although small differences from the planned amounts were seen. This was due to the planned increases of the amounts of supplement after calving, and the calibration of the automatic feeding stations. However, these differences were therefore equal across treatments.

The net energy intake was equal for treatments $\mathrm{C}$ and $\mathrm{R} / \mathrm{C}$ within experiment and treatment $\mathrm{R}$ provided as expected 1.7 Scandinavian feed units (SFU) less than the other treatments in experiment 1 . The level of fatty acids in ration $\mathrm{C}$ was low according to the Danish Requirements (Strudsholm et al., 1999) and the level of fatty acids in ration $\mathrm{R} / \mathrm{C}$ was high according to the Danish Requirements (Table 3). The level of AAT was below minimum requirement in ration $\mathrm{R} / \mathrm{C}$. The protein level was lower in experiment 1 than in 2, which was due to a low level of crude protein in the highly-digestible clover grass silage used in experiment 1 (Table 2).

\section{Daily milk yield, somatic cell counts and urea}

Daily milk yield, energy corrected milk yield, content of fat and protein, urea and SCC in the two experiments during period 1 are shown in Tables 4 and 5, and for the aggregated analyses in Table 6 .

In experiment 1 , milk yield was higher $(P=0.03)$ in treatment $\mathrm{R} / \mathrm{C}$ than in treatments $\mathrm{C}$ and $\mathrm{R}$. Although both fat and protein percentage were numerically lower in treatment $\mathrm{R} / \mathrm{C}$ than in treatment $\mathrm{C}$, the differences were not statistically significant. Treatment had a significant effect on ECM yield $(P=0.05)$. The 
Table 3. Actual daily feed intake in kg dry matter (DM) per cow and in brackets Scandinavian Feed Unit (SFU), energy intake and content of nutrients

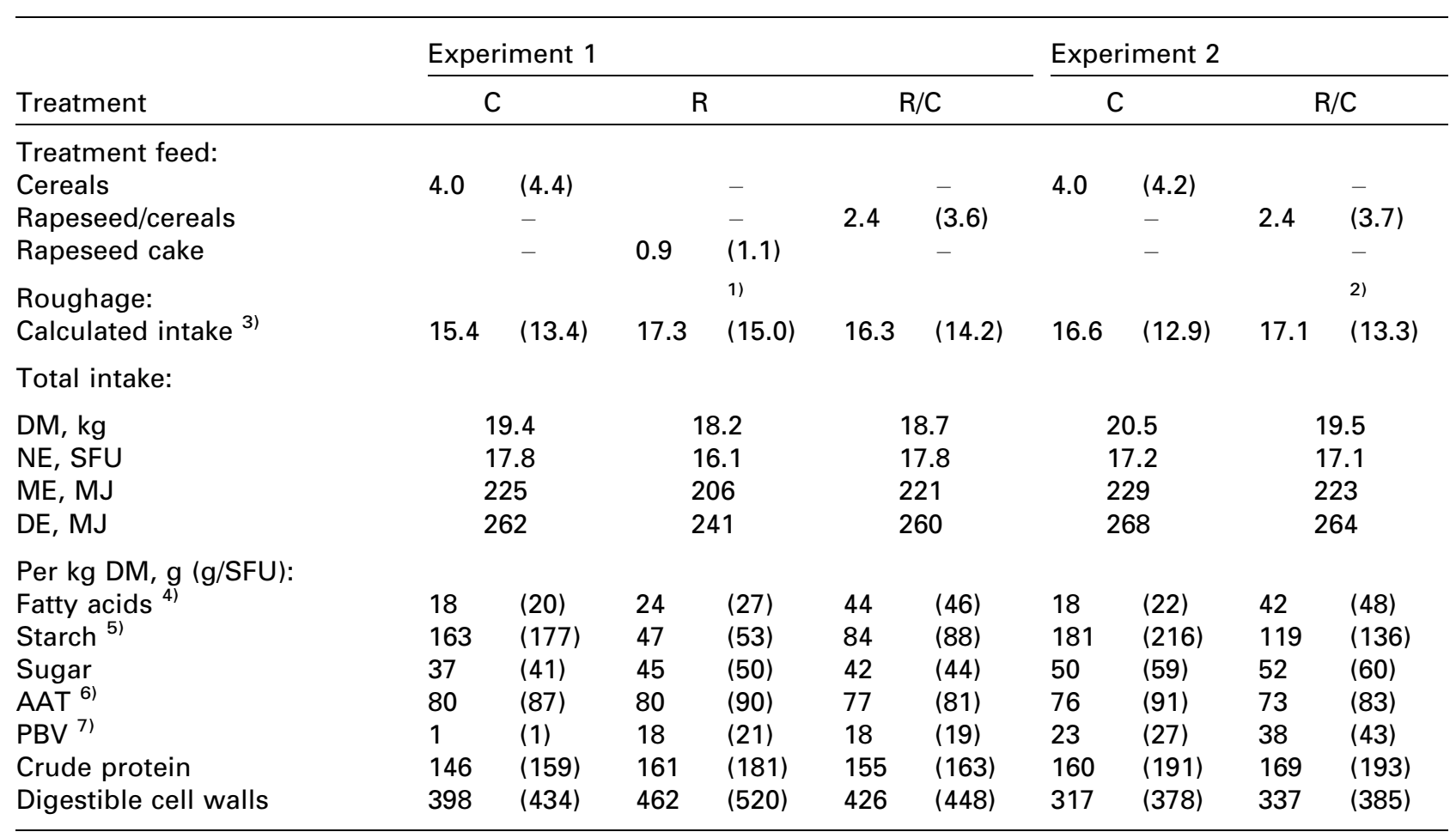

1) $63 \%$ clover grass silage, $19 \%$ barley and pea whole crop, and $18 \%$ grass pellets (percentage of $\mathrm{kg} \mathrm{DM}$ ).

2) $20 \%$ clover grass silage, $53 \%$ barley and pea whole crop, and $27 \%$ grass pellets (percentage of $\mathrm{kg} \mathrm{DM}$ ).

3) Roughage intake was calculated using the Danish Fill Unit System.

4) Danish requirement (Strudsholm et al., 1999).

$\begin{array}{llll}\text { Minimum: } & 20 \mathrm{~g} / \mathrm{SFU} & \text { Maximum: } & 47 \mathrm{~g} / \mathrm{SFU} \\ \text { 5) } & - & & 280 \mathrm{~g} / \mathrm{SFU} \\ 6) & 90 \mathrm{~g} / \mathrm{SFU} & & - \\ 7) & 0 \mathrm{~g} / \mathrm{SFU} & & 50 \mathrm{~g} / \mathrm{SFU}\end{array}$

Table 4. Daily milk yield and milk composition in experiment 1, LSmeans \pm s.e.

\begin{tabular}{|c|c|c|c|c|c|c|c|}
\hline Treatment & \multicolumn{2}{|c|}{$C$} & \multicolumn{2}{|c|}{$\mathrm{R}$} & \multicolumn{2}{|c|}{$\mathrm{R} / \mathrm{C}$} & $P$-value \\
\hline Number of cows & \multicolumn{2}{|c|}{29} & \multicolumn{2}{|c|}{27} & \multicolumn{2}{|c|}{32} & \\
\hline DIM ${ }^{11}$ & \multicolumn{2}{|c|}{128} & \multicolumn{2}{|c|}{132} & \multicolumn{2}{|c|}{120} & \\
\hline Pre-yield ${ }^{2)}$ & \multicolumn{2}{|c|}{26.6} & \multicolumn{2}{|c|}{26.2} & \multicolumn{2}{|c|}{26.6} & \\
\hline Parity & \multicolumn{2}{|c|}{2.7} & \multicolumn{2}{|c|}{2.4} & \multicolumn{2}{|c|}{2.7} & \\
\hline ECM, kg & 24.0 & $0.6^{1), 2)}$ & 23.4 & $0.6^{1)}$ & 25.3 & $0.5^{2)}$ & 0.05 \\
\hline Milk, kg & 24.4 & $0.7^{1)}$ & 24.3 & $0.7^{1)}$ & 26.5 & $0.6^{21}$ & 0.03 \\
\hline $\begin{array}{l}\text { Fat, g } \\
\text { Fat, \% }\end{array}$ & $\begin{array}{l}1003 \\
4.13\end{array}$ & $\begin{array}{l}28 \\
0.1\end{array}$ & $\begin{array}{l}941 \\
3.96\end{array}$ & $\begin{array}{l}30 \\
0.1\end{array}$ & $\begin{array}{l}1033 \\
3.95\end{array}$ & $\begin{array}{l}27 \\
0.1\end{array}$ & $\begin{array}{l}0.07 \\
0.29\end{array}$ \\
\hline $\begin{array}{l}\text { Protein, g } \\
\text { Protein, \% }\end{array}$ & $\begin{array}{l}760 \\
3.13\end{array}$ & $\begin{array}{l}19 \\
0.04\end{array}$ & $\begin{array}{l}740 \\
3.10\end{array}$ & $\begin{array}{l}20 \\
0.04\end{array}$ & $\begin{array}{l}793 \\
3.03\end{array}$ & $\begin{array}{l}18 \\
0.04\end{array}$ & $\begin{array}{l}0.13 \\
0.20\end{array}$ \\
\hline $\begin{array}{l}\operatorname{Ln}(\mathrm{SCC}) \\
\text { Urea, mM }\end{array}$ & $\begin{array}{l}4.78 \\
3.10\end{array}$ & $\begin{array}{l}0.16 \\
0.06^{1)}\end{array}$ & $\begin{array}{l}4.81 \\
3.52\end{array}$ & $\begin{array}{l}0.17 \\
0.06^{2)}\end{array}$ & $\begin{array}{l}4.86 \\
3.43\end{array}$ & $\begin{array}{l}0.15 \\
0.06^{2)}\end{array}$ & $\begin{array}{l}0.93 \\
0.0001\end{array}$ \\
\hline
\end{tabular}

The letters correspond to a significance level of 0.05 .

1) Days in milk, average during experimental period.

2) Last milk yield registration before the start of the experiment. 
- Paper IV Organic dairy production and supplementary feeds

Table 5. Milk yield and milk composition in experiment 2, LSmeans \pm s.e

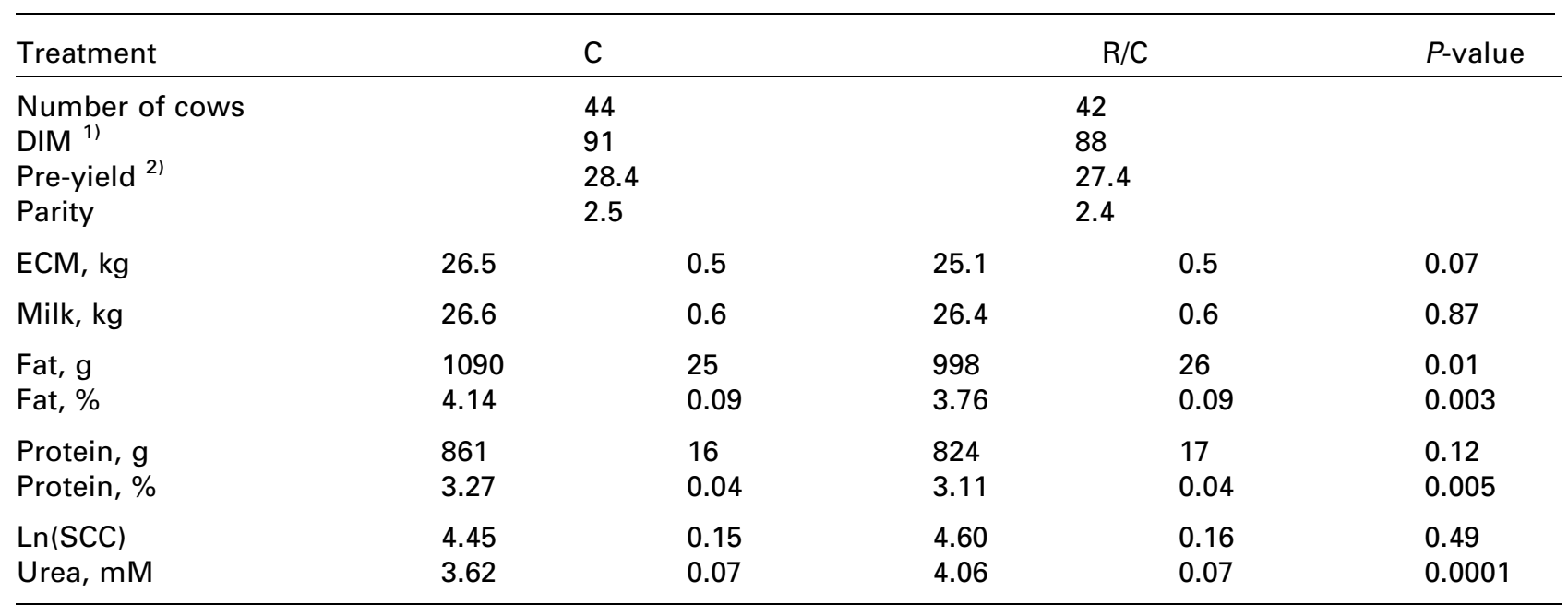

1) Days in milk, average during experimental period.

2) Last milk yield registration before the start of the experiment.

ECM yield tended to be higher $(P=0.09)$ in treatment $\mathrm{R} / \mathrm{C}$ than in $\mathrm{C}$, and the ECM yield was higher $(P=$ 0.02 ) in treatment $\mathrm{R} / \mathrm{C}$ than in $\mathrm{R}$ (Table 4).

In experiment 2, there was no significant effect of treatment on milk yield. Both fat content $(P=0.003)$ and protein content $(P=0.005)$ were lower in treatment $\mathrm{R} / \mathrm{C}$ than in $\mathrm{C}$. Therefore, the ECM yield tended to be lower in treatment $\mathrm{R} / \mathrm{C}$ than in $\mathrm{C}(P=0.07)$ (Table 5).

Even though both experiments showed lower fat and protein contents, the aggregated analyses (Table 6)

Table 6. Milk yield and milk composition with cereals (C) and rapeseed/cereals $(\mathrm{R} / \mathrm{C})$ across experiments 1 and 2, LSmeans \pm s.e

\begin{tabular}{llllll}
\hline Treatment & \multicolumn{2}{c}{ C } & \multicolumn{2}{c}{$\mathrm{R} / \mathrm{C}$} & $P$-value \\
\hline Number & \multicolumn{2}{c}{73} & \multicolumn{2}{c}{74} & 147 \\
ECM, kg & 25.4 & 0.4 & 25.4 & 0.4 & 0.98 \\
Milk, kg & 25.7 & 0.5 & 26.8 & 0.5 & 0.53 \\
Fat, g & 1052 & 19 & 1024 & 19 & 0.73 \\
Fat, \% & 4.14 & 0.07 & 3.85 & 0.07 & 0.16 \\
Protein, g & 814 & 13 & 814 & 13 & 0.99 \\
Protein, \% & 3.20 & 0.03 & 3.06 & 0.03 & 0.10 \\
Ln(SCC) & 4.62 & 0.11 & 4.70 & 0.11 & 0.55 \\
Urea, mM & 3.36 & 0.05 & 3.74 & 0.05 & 0.10 \\
Gain, kg & -11 & 6 & -15 & 6 & 0.59 \\
$\Delta$ BCS & 0.01 & 0.05 & 0.01 & 0.05 & 0.92 \\
\hline
\end{tabular}

$P$-value $=$ effect of treatment with farm*treatment as error term. only showed weak tendencies for lower fat $(P=0.16)$ and protein $(P=0.10)$ content in treatment $\mathrm{R} / \mathrm{C}$ compared with treatment $C$. No significant effects of feeding were seen on milk or ECM yield as the two experiments had shown opposite results. The mean somatic cell count did not differ between treatments $(P=0.55)$. The mean urea level was lower in treatment $\mathrm{C}$ than in the other treatments $(P=0.10)$ (Table 6).

Table 7 gives a comparison between treatments R/C and $\mathrm{C}$ separated into first or later parity for the two experiments. It shows that the higher milk yield in treatment $\mathrm{R} / \mathrm{C}$ in experiment 1 particularly was caused by older cows in early lactation, which yielded $4.8 \mathrm{~kg}$ milk more than those in treatment $\mathrm{C}$. In contrast, in treatment $\mathrm{R} / \mathrm{C}$ in experiment 2 , older cows in early lactation yielded $3.5 \mathrm{~kg}$ less than those in treatment $\mathrm{C}$. Fig. 1 gives the curves of lactation for cows in treatments $\mathrm{R} / \mathrm{C}$ and $\mathrm{C}$ for the two experiments. Table 7 further indicates that the milk fat percentage was especially lower in treatment $\mathrm{R} / \mathrm{C}$ for older cows in late lactation in experiment 2, the difference being 0.62 point. Also, the protein percentage was particularly low for older cows in late lactation in experiment 2 , the difference being 0.31 point.

\section{Metabolites in plasma and milk}

The concentrations of metabolites in plasma and milk for the different treatments are shown in Tables 8 and 9. Neither the concentration of $\beta$-hydroxybutyrate, nor glucose in plasma or $\beta$-hydroxybutyrate in milk were affected by treatment. However, in experiment 1 , NEFA tended to be affected by treatment $(P=0.11)$, with the lowest level in treatment $\mathrm{R} / \mathrm{C}$ and the highest level in treatment $\mathrm{R}$. The level of $\beta$-hydroxybutyrate in 
Table 7. Differences between rape seed and cereal treatment (a positive difference if rape seed $>$ cereal treatment) for cows in early or late stage of lactation and for first parity or older cows

\begin{tabular}{|c|c|c|c|c|}
\hline \multirow[b]{2}{*}{ Stage of lactation } & \multicolumn{2}{|c|}{ Experiment 1} & \multicolumn{2}{|c|}{ Experiment 2} \\
\hline & Early & Late & Early & Late \\
\hline \multicolumn{5}{|l|}{ First parity } \\
\hline Number of cows & 9 & 9 & 19 & 19 \\
\hline \multicolumn{5}{|c|}{ Rape seed vs. cereal } \\
\hline $\mathrm{kg} \mathrm{ECM}$ & 0 & 1.5 & -0.5 & -1.2 \\
\hline kg milk & 1.2 & 1.7 & 0.6 & -0.1 \\
\hline fat, $\%$ & -0.34 & -0.19 & -0.34 & -0.37 \\
\hline protein, \% & -0.05 & -0.07 & -0.10 & -0.21 \\
\hline \multicolumn{5}{|c|}{ Second parity or greater } \\
\hline Number of cows & 23 & 21 & 24 & 24 \\
\hline \multicolumn{5}{|c|}{ Rape seed vs. cereal } \\
\hline $\mathrm{kg} \mathrm{ECM}$ & 4.5 & 0.2 & -3.9 & -0.1 \\
\hline kg milk & 4.8 & 1.7 & -3.5 & 1.9 \\
\hline fat, \% & 0.06 & -0.31 & -0.14 & -0.62 \\
\hline protein, \% & -0.03 & -0.25 & 0.02 & -0.31 \\
\hline
\end{tabular}

plasma was significantly higher in experiment 1 than 2 , whereas the opposite was seen for glucose. $\beta$-hydroxybutyrate in plasma and milk were positively correlated in both experiments $(r=0.27, \quad P=0.0001)$,
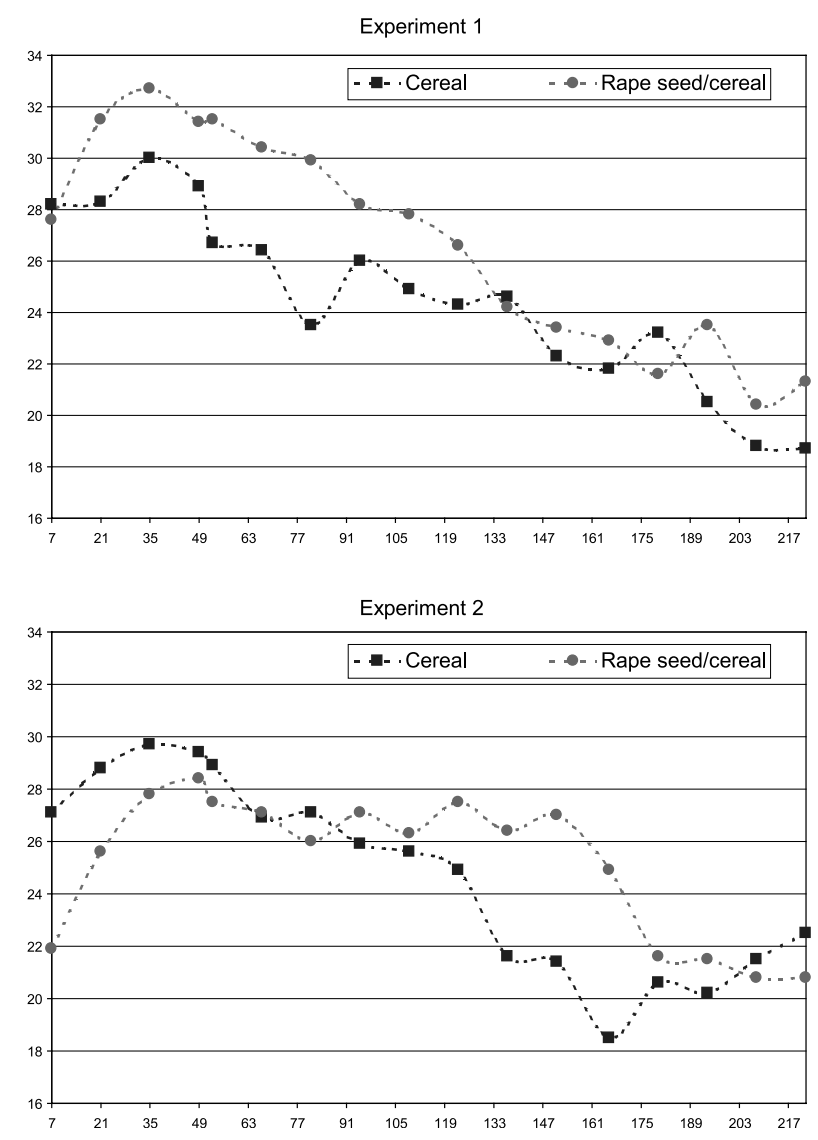

Fig. 1. Milk yield responses ( $\mathrm{kg}$ ) from supplement of rapeseed/ cereals $(\mathrm{R} / \mathrm{C})$ or cereals $(\mathrm{C})$ during the lactation (days post partum). whereas the negative correlations between glucose and $\beta$-hydroxybutyrate in plasma $(r=-0.16, P=0.006)$ and NEFA $(r=-0.15, P=0.007)$ only were seen in experiment 2 .

\section{Live weight gain, body condition score and health}

Neither live weight gain nor BCS were affected by treatments in any of the experiments. However, differences could occur within the period. The prevalences of clinical disorders are shown in Table 10. No difference in the frequency of disorders between treatments was found in either experiment.

\section{Discussion}

Supplement of rapeseed/cereal pellets compared with barley did not affect milk yield

The aggregated analysis showed that milk yield was unaffected by supplement of rapeseed/cereal pellets or barley. However, the two experiments showed different tendencies. In experiment 2 milk yield was unaffected, and in experiment 1 milk yield was increased by $9 \%$, probably due to an increase of fat level in the ration from 1.8 to $4.3 \%$ of DM. Coincidently, level of starch decreased from 16.3 to $8.4 \%$ of DM. The hypothesis was to substitute rapeseed/cereals for barley because a higher level of fat in the ration has shown a positive effect on milk production (Østergaard et al., 1981; Hermansen \& Østergaard, 1988; Sutton \& Morat, 1989; Khorasani et al., 1991; Schingoethe \& Casper, 1991). An increased milk yield may be explained by a more efficient milk production when de novo synthesis 
- Paper IV Organic dairy production and supplementary feeds

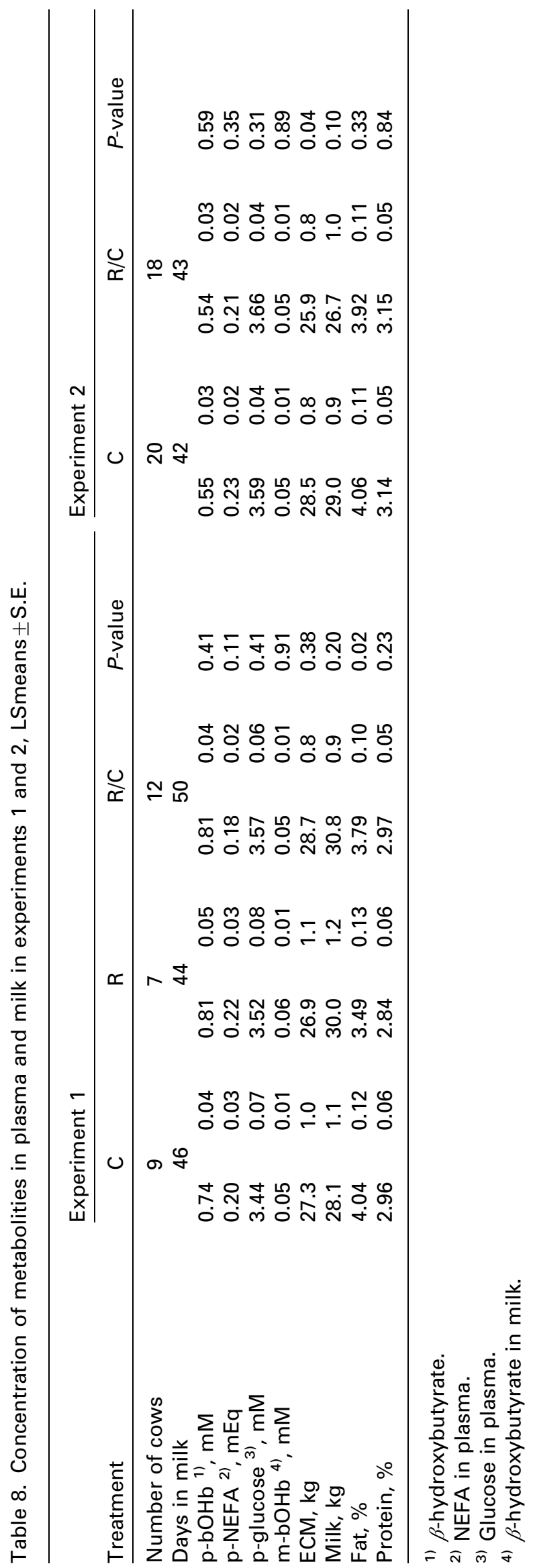

Table 9. Concentration of metabolites in plasma and milk across experiments 1 and 2, LSmeans \pm s.e

\begin{tabular}{llllll}
\hline Treatment & & $\mathrm{C}$ & & $\mathrm{R} / \mathrm{C}$ & $P^{5)}$ \\
\hline Number of cows & & 29 & & 30 \\
Days in milk & & 43 & & 46 & \\
p-bOHb ${ }^{1)}, \mathrm{mM}$ & 0.64 & 0.02 & 0.66 & 0.02 & 0.63 \\
p-NEFA $^{2}{ }^{\prime}, \mathrm{mEq}$ & 0.21 & 0.02 & 0.19 & 0.01 & 0.22 \\
p-glucose $^{3)}, \mathrm{mM}$ & 3.51 & 0.04 & 3.62 & 0.04 & 0.37 \\
m-bOHb $^{4)}, \mathrm{mM}$ & 0.05 & 0.006 & 0.05 & 0.006 & 0.36 \\
ECM, kg & 27.9 & 0.7 & 27.2 & 0.7 & 0.81 \\
Milk, kg & 28.5 & 0.8 & 28.7 & 0.7 & 0.96 \\
Fat, \% & 4.04 & 0.09 & 3.85 & 0.08 & 0.16 \\
Protein, \% & 3.06 & 0.04 & 3.06 & 0.04 & 0.69 \\
\hline
\end{tabular}

1) $\beta$-hydroxybutyrate.

2) NEFA in plasma.

3) Glucose in plasma.

4) $\beta$-hydroxybutyrate in milk.

5) $P$-value $=$ effect of treatment with farm*treatment as error term.

of milk fatty acids based on acetate as substrate is decreased due to incorporation of added dietary fatty acids in milk (Wu \& Huber, 1994).

The fat type in these earlier Danish experiments was animal fat. Fat from rapeseeds as in our experiment, contains more polyunsaturated fatty acids, which may inhibit ruminal microbial growth, fibre digestion (Sutton \& Morat, 1989), DM digestibilities as well as the proportion of DM digested in the rumen (Murphy et al., 1987). However, full-fat oil seeds with a relatively slow release of fat appear to have less negative impact on ruminal fermentation than free oil or fat (Murphy et al., 1987). Hermansen \& Østergaard (1988) even concluded that rapeseed was a fat supply just as suitable as animal fat, provided that the product of gram fatty acids and iodine value was below 7,500 g/ $\mathrm{kg}$ DM.

A reason for the different findings in the present experiments 1 and 2 might be that factors such as energy status and stage of lactation (Østergaard et al., 1981; Khorasani \& Kennelly, 1998) as well as the composition of the ration (Smith et al., 1993; Tackett et al., 1996) can affect the milk yield response of an increased fat supply. Østergaard et al. (1981) and Khorasani \& Kennelly (1998) argued that stage of lactation is an important factor moderating the response to dietary fat as less or no response was found in mid to late lactation. This was probably because these cows often are in a neutral or positive energy balance (Khorasani et al., 1991). In experiment 1 , cows in early lactation responded with increased milk yield from increased fat. However, cows in experiment 2 with no response of increased fat supply 


\section{Mogenesen et al.}

on milk yield were one month closer to calving than cows in experiment 1. A low level of $\beta$-hydroxybutyrate indicated that most cows had passed the critical period after calving in both experiments.

Another possible explanation of the different effects in experiments 1 and 2 could be differences in roughage quality. The proportion of whole crop silage was higher and proportion of clover grass silage lower in experiment 2 compared to 1 . The average in vitro digestibility of the roughage was $72 \%$ in experiment 2 and $77 \%$ in experiment 1 . This could have influenced the intake of roughage, especially for the high yielding cows fed a low level supplement (R/C). Therefore, further research including intake of the ad libitum feed is needed.

\section{Increased supply of fatty acids tended to decrease milk protein content}

In the aggregated analyses, the protein yield was unaffected but the protein content tended to be lowered by an increased supply of fatty acids. In experiment 1, an increased milk yield and a maintained protein yield resulted in a lower protein content due to the dilution effect. These findings are in accordance with Chilliard (1993), who found a negative effect on protein content of fat supply of all types, and throughout the lactation, and with experiments by Sutton \& Morat (1989), Spörndly (1989), Khorasani et al. (1991), Tackett et al. (1996), Khorasani \& Kennelly (1998) and Bayourthe et al. (2000).

In experiment 2, where milk yield was unaffected by fatty acids supply, the protein content was lowered. This could be due to a lower intake of energy (Spörndly, 1989; Wu \& Huber, 1994; Khorasani \& Kennelly, 1998). However, the energy status, indicated by glucose and $\beta$-hydroxybutyrate, did not differ between treatments. In agreement with our findings,
Bayourthe et al. (2000) found a greater milk protein depression during later lactation.

\section{Increased supply of fatty acids tended to decrease milk fat content}

In the aggregated analyses, the fat yield was unaffected and the fat content tended to be reduced by an increased supply of fatty acids. Results by Hermansen \& Østergaard (1988), Hermansen et al. (1995) and Tackett et al. (1996) are in accordance with our results. Also Chilliard (1993) observed a decreased milk fat content in experiments with vegetable fat, whereas other experiments have shown a considerable difference in milk fat response to fat supply (Chilliard, 1993).

That fat supplements can both increase and decrease fat concentration in milk may be due to the balance between decreased de novo synthesis of short- and medium-chain fatty acids and the extent of incorporation of additional dietary long-chain fatty acids into milk fat (Sutton \& Morat, 1989; Khorasani et al., 1991; Tesfa, 1993). Furthermore, unsaturated fatty acids can be converted into CLA-isomer, which can inhibit de novo synthesis and thereby reduce fat content in milk (Bauman \& Griinari, 2001; Baumgard et al., 2001).

\section{Supplement of rapeseed/cereal pellets compared with barley did not affect ECM yield}

The aggregated analysis showed that ECM yield was unaffected by supplement of rapeseed/cereal pellets or barley. Østergaard et al. (1981) found a 6\% higher ECM yield when the fat content was increased from $1.8 \%$ to $4.4 \%$ of DM. The relatively high response on ECM yield of increased fat, as observed by Østergaard et al. (1981), was not supported by data in a more

Table 10. Incidence (new cases per 16 weeks) of disorders

\begin{tabular}{|c|c|c|c|c|c|}
\hline \multirow[b]{2}{*}{ Treatment } & \multicolumn{3}{|c|}{ Experiment 1} & \multicolumn{2}{|c|}{ Experiment 2} \\
\hline & C & $\mathrm{R} / \mathrm{C}$ & $\mathrm{R}$ & $\mathrm{C}$ & $\mathrm{R} / \mathrm{C}$ \\
\hline Total number of cows at risk & 29 & 27 & 32 & 44 & 42 \\
\hline Mastitis & 4 & 6 & 3 & 1 & 5 \\
\hline Reproductive ${ }^{1)}$ & 0 & 0 & 0 & 0 & 2 \\
\hline Digestion/metabolic ${ }^{2)}$ & 1 & 0 & 0 & 1 & 0 \\
\hline Limb disorders & 0 & 0 & 1 & 1 & 0 \\
\hline Problems at calving ${ }^{3)}$ & 2 & 4 & 1 & 2 & 1 \\
\hline Total numbers of disorders ${ }^{4)}$ & 6 & 9 & 5 & 5 & 8 \\
\hline
\end{tabular}

\footnotetext{
1) Uterus inflammation, retained placenta.

2) Milk fever.

3) Abortion, calving with assistance.

4) Each cow is counted only once.
} 
recent review by Chilliard (1993). He found an increase of $0.07-0.20 \mathrm{~kg}$ fat corrected milk per percentage of higher fat content in the ration of DM. The review included several fat types including vegetable oil and oilseeds, which have shown a negative effect on ECM yield by increased fat supply (Chilliard, 1993; Murphy et al., 1995a). Other experiments have found no effect on FCM yield from increased fat supply (Emanuelson et al., 1993, Murphy et al., 1995b).

\section{Supplement of rapeseed cake compared with barley affected neither milk yield nor composition}

These findings followed the expectations that the lower energy intake in treatment $\mathrm{R}$ would not be totally compensated for by the positive effect of the more balanced composition of nutrients including a higher level of fatty acids (Østergaard et al., 1981) and AAT (Kristensen, 1997). That the milk fat content was not affected may be due to a positive effect of the frequent allocation of barley (Ørskov, 1999). According to König et al. (1984) cows given low energy diets utilise additional protein supply as energy source and not for higher milk protein output.

\section{Type of supplement affected neither risk of subclinical ketosis nor health}

Vaarst (1995) found that organic cows secrete acetone above the level for detection later in lactation than conventional cows. In the present experiment, the concentration of metabolites measured in plasma and milk was found to be within the normal physiological range (Enjalbert et al., 2001) indicating that none of the treatments resulted in excessive negative energy balance during the first 12 weeks of lactation. Cows offered only $1 \mathrm{~kg}$ rapeseed cake were expected to increase mobilisation to meet the physiological needs. This was obviously not the case, as indicated by normal glucose concentrations in plasma (Veenhuizen et al., 1991). It was concluded that the average cow in the present experiment had no risk of ketosis, mainly because of an average BCS of 2.5 and a consequent relative low mobilisation of body fat. This, together with high quality roughage ad libitum prevented an increased level of $\beta$-hydroxybutyrate and hypoglycaemia. In agreement with our results, Emanuelson et al. (1993) and Ahlin et al. (1994) found no difference in total disease rate between different levels of fat supply.

\section{On-farm production of fodder crops and milk}

Assuming the level of feed intake and milk yield from the present experiments, 100 ha of land make it possible to grow the cereal ration for 76 cows, the rapeseed cake ration for 83 cows and the rapeseed/ cereal ration for 77 cows in experiment 1 . Correspondingly, the cereal ration can be grown for 71 cows, and the rapeseed/cereal ration for 73 cows on 100 ha in experiment 2. The total ECM production on 100 ha will be increased by $6 \%$ if choosing the rapeseed cake or rapeseed/cereal rations compared with the cereal ration in experiment 1 . However, in experiment 2 the total ECM production will be decreased by $3 \%$ if choosing rapeseed/cereal compared with cereal. The income from milk will fluctuate proportionally to the ECM yield as the differences in milk composition and yield in $\mathrm{kg}$ result in the same income per $\mathrm{kg}$ ECM. Which crop to choose to grow, and also the variation in crop yield, need careful consideration. One possible explanation for the different responses on milk yield of increased levels of fat in the two experiments could be differences in roughage quality. Generally, the roughage in the present experiments was highly digestible, and a lower quality roughage might result in a different conclusion. This emphasizes the importance of producing and feeding high quality roughage, the keystone in organic feeding of dairy cows.

\section{Acknowledgements}

Financial support for this research was provided by the Danish Ministry of Food, Agriculture and Fisheries through the programme 'Research in organic farming 2000-2005' (DARCOF II). The authors express their thanks to the farmers Erik Andersen and Bent Nielsen for hosting the experiments, the research assistants Gunnar Grønning and Helge Yde and the farm advisers Anders Møller and Knud Møller, for the on-farm registration. We also wish to thank for the skilful help during sampling and analysis of samples given by the laboratory technicians D. Agnholt and Jens B. Clausen.

\section{References}

Ahlin, K. A., Emanuelson, M. \& Wiktorsson, H. 1994. Rapeseed products from double-low cultivars as feed for dairy cows: effects of long-term feeding on thyroid function, fertility and animal health. Acta Veterinaria Scandinavica 35, 37-53.

Bauman, D. E. \& Griinari, J. M. 2001. Regulation and nutritional manipulation of milk fat: low-fat milk syndrome. Livest. Prod. Sci. 70, 15-29.

Baumgard, L. H., Sangster, J. K. \& Bauman, D. E. 2001. Milk fat synthesis in dairy cows is progressively reduced by increasing supplemental amounts of trans-10,cis-12 conjugated linoleic acid (CLA). J of Nutrition. 131, 1764-1769.

Bayourthe, C., Enjalbert, F. \& Moncoulon, R. 2000. Effects of different forms of canola oil fatty acids plus canola meal on milk 


\section{Mogenesen et al.}

composition and physical properties of butter. J Dairy Sci. 83, 690-696.

Chilliard, Y. 1993. Dietary fat and adipose tissue metabolism in ruminants, pigs and rodents: a review. J Dairy Sci. 76, 38973931.

Council for The European Union. 1999. Ordinance No 1804/1999 of July 1999. Supplementing Regulation (EEC) No 2092/91. Official Journal of the European Union L 222. Bruxelles, 28 pp.

Dhiman, T. R., Kleinmans, J., Tessmann, N. J., Radloff, H. D. \& Satter, L. D. 1995. Digestion and energy balance in lactating dairy cows fed varying rations of alfalfa silage and grain. J Dairy Sci. 78, 330-341.

Emanuelson, M., Ahlin, K. Å. \& Wiktorsson, H. 1993. Long term feeding of rapeseed meal and full fat rapeseed of double low cultivars to dairy cows. Livest. Prod. Sci. 33, 199-214.

Enjalbert, F., Nicot, M. C., Bayourthe, C. \& Moncoulon, R. 2001. Ketone bodies in milk and blood of dairy cows: relationship between concentration and utilisation for detection of subclinical ketosis. J Dairy Sci. 84, 583-589.

Harano, Y., Ohtsuki, M., Ida, M., Kojima, H., Harada, M., Okanisihi, T. et al., 1985. Direct automated assay method for serum or urine levels of ketone bodies. Clinica Chimica Acta. $151,177-183$.

Helrich, K. 1990. Official methods of the analysis of the AOAC. $15^{\text {th }}$ edition. Association of the Official Analytical Chemists, $684 \mathrm{pp}$.

Hermansen, J. E., Aaes, O., Ostersen, S. \& Vestergaard, M. 1995 Rapeseed products for dairy cows: milk yield and milk quality. Report No. 29. National Institute of Animal Science, Denmark. 31 pp. (In Danish.)

Hermansen, J. E. \& Østergaard, V. 1988. Oilseed as dietary fat supplement for dairy cows: rapeseed, soyabeans, linseed. Report No. 636. National Institute of Animal Science, Denmark. 44 pp. (In Danish.)

IFOAM, 2000. The Principal Aims of Organic Production and Processing. IFOAM basic standards, Basel.

Khorasani, G. R. \& Kennelly, J. J. 1998. Effect of added dietary fat on performance, rumen characteristics and plasma metabolites of mid-lactation dairy cows. J Dairy Sci. 81, 2459-2468.

Khorasani, G. R., Robinson, P. H., de Boer, G. \& Kennelly, J. J. 1991. Influence of canola fat on yield, fat percentage, fatty acids profile, and nitrogen fractions in Holstein milk. J Dairy Sci. 74, 1904-1911.

Kristensen, T. 1986. Method for estimation of body condition of dairy cows. Report No. 615. National Institute of Animal science, Denmark. 59-75. (In Danish.)

Kristensen, V. F. 1997. Optimal proteinforsyning (optimum protein supply). Internal report No. 88. DIAS, Denmark. 46-55. (In Danish.)

Kronfeld, D. S. 1982. Major metabolic determinants of milk volume, mammary efficiency and spontaneous ketosis in dairy cows. J Dairy Sci. 65, 2204-2212.

Kunz, P. L., Blum, J. W., Hart, I. C., Bickel, H. \& Landis, J. 1985. Effects of different energy intakes before and after calving on food intake, performance and blood hormones and metabolites in dairy cows. Anim. Prod. 40, 219-231.

König, B. A., Oldham, J. D. \& Parker, D. S. 1984. The effect of casein on acetate, palmitate and glucose kinetics in cows during early lactation. Br. J. Nutr. 52, 319-328.

Madsen, J., Hvelplund, T., Weisbjerg, M. R., Bertilsson, J., Olsson, I., Spörndly, R., et al. 1995. The AAT/PBV protein evaluation system for ruminants. A revision. The Norwegian Journal of Agricultural Sciences 19, 1-37.

Mashek, D. G., Ingvartsen, K. L., Andersen, J. B., Vestergaard, M. \& Larsen, T. 2001. Effects of a four-day hyperinsulinaemic- euglycaemic clamp in early and mid-lactation dairy cows on plasma concentrations of metabolites, hormones, and binding proteins. Domestic Animal Endocrinology 21, 169-185.

Mogensen, L., Kristensen, T. \& Kristensen, I. S. 1999. Organic cattle production. Technical and economic results from farm studies 1997-98. Typical level of organic milk production in Denmark. Report No. 10. DIAS, Denmark. 138 pp. (In Danish.)

Murphy, J. J., Connolly, J. F. \& McNeill, G. P. 1995a. Effects on cow performance and milk fat composition of feeding full fat soyabeans and rapeseeds to dairy cows at pasture. Livest. Prod. Sci. 44, 13-25.

Murphy, J. J., Connolly, J. F. \& McNeill, G. P. 1995b. Effects on milk fat composition and cow performance of feeding concentrates containing full fat rapeseed and maize distillers grains on grass silage based diets. Livest. Prod. Sci. 44, 1-11.

Murphy, M., Uden, P., Palmquist, D. L. \& Wiktorsson, H. 1987. Rumen and total diet digestibilities in lactating cows fed diets containing full-fat rapeseed. J Dairy Sci. 70, 1572.

Ørskov, E. R. 1999. Supplement strategies for ruminants and management feeding to maximize utilisation of roughage. Preventive Veterinary Medicine 38, 179-185.

Østergaard, V., Danfær, A., Daugaard, J., Hindhede, J. \& Thysen, I. 1981. The effect of dietary lipids on milk production in dairy cows. Report No. 508. National Institute of Animal Science, Denmark. 140 pp. (In Danish.)

SAS Institute Inc. 1990. SAS/STAT User's Guide, Vol. 2. Vers. 6, $4^{\text {th }}$ edition. Gary, NC. 893-1686.

Schingoethe, D. J. \& Casper, D. P. 1991. Total lactational response to added fat during early lactation. J Dairy Sci. 74, 2617-2622.

Sjaunja, L. O., Baevre, L., Junkkarinen, L., Pedersen, J. \& Setälä, J. A. 1990. Nordic proposal for an energy-corrected milk (ECM) formula. ICRPMA. $27^{\text {th }}$ session, Paris 2-6 July.

Smith, W. A., Harris, J., Van Horn, H. H. \& Wilcox, C. J. 1993. Effects of forage type on production of dairy cows supplemented with whole cottonseed, tallow and yeast. J Dairy Sci. 76, 205.

Spörndly, E. 1989. Effect of diet on milk composition and yield of dairy cows with special emphasis on milk protein content. Swedish J. Agric. Res. 19, 99-106.

Strudsholm, F., Nielsen, E. S., Flye, J. C., Kjeldsen, A. M., Weisbjerg, M. R., Søegaard, K., et al. 1997. Fodermiddeltabel 1997 (Feed tables. Composition and nutritional value for cattle). Report No. 69. The National Committee on Cattle Husbandry. Denmark. 53 pp. (In Danish.)

Strudsholm, F., Aaes, O., Madsen, J., Kristensen, V. F., Andersen, H. R., Hvelplund, T. \& Østergaard, S. 1999. Danske fodernormer til kvæg (Danish feed recommendations for cattle). Report No. 84. The National Committee on Cattle Husbandry. Denmark. 47 pp. (In Danish.)

Sutton, J. D. \& Morat, S. V. 1989. A review of the potential of nutrition to modify milk fat and protein. Livest. Prod. Sci. 23, 219-237.

Tackett, V. L., Bertrand, J. A., Jenkins, T. C., Pardue, F. E. \& Grimmes, L. W. 1996. Interaction of dietary fat and acid detergent fibre diets of lactating dairy cows. J Dairy Sci. 79, $270-275$.

Tesfa, A. T. 1993. Effects of rapeseed oil supplementation on digestion, microbial protein synthesis and duodenal microbial amino acid composition in ruminants. Anim. Feed Sci. and Technol. 41, 313-328.

Tilley, J. M. A. \& Terry, R. A. 1963. A two-stage technique for the in vitro digestion of forage crops. J. Bri. Grassl. Soc. 18, 104-111.

Vaarst, M. 1995. Health and disease control in Danish organic herds. Ph.D. Thesis. The Royal Veterinary and Agricultural University, Denmark. 55-68. 


\section{- Paper IV Organic dairy production and supplementary feeds}

Veenhuizen, J. J., Drackley, J. K., Richard, M. J., Sanderson, T. P., Miller, L. D. \& Young, J. W. 1991. Metabolic changes in blood and liver during development and early treatment of experimental fatty liver and ketosis in cows. J Dairy Sci. 74, 4238-4253.
Waldo, D. R. 1986. Effect of forage quality on intake and forageconcentrate interactions. J Dairy Sci. 69, 617-631.

Wu, Z. \& Huber, J. T. 1994. Relationship between dietary fat supplementation and milk protein concentration in lactating cows. A review. Livest. Prod. Sci. 39, 141-155. 